\title{
Status and distribution of available micronutrients along a toposequence at Bazargaon plateau, Maharashtra
}

\section{JAYAN. GIRI, NILIMAS. SADANSHIV AND PRAJAKTA M. METKARI}

Received : 11.10.2017; Revised : 13.11.2017; Accepted : 22.11.2017

MEMBERS OF RESEARCH FORUM:
Corresponding author :
JAYA N. GIRI, Department
of Soil Science and Agricultural
Chemistry, Dr. Panjabrao Deshmukh
Krishi Vidyapeeth, AKOLA (M.S)
INDIA
INDIA
Co-authors :

NILIMA S. SADANSHIV AND PRAJAKTA M. METKARI, Department of Soil Science and Agricultural Chemistry, Dr. Panjabrao Deshmukh Krishi Vidyapeeth, AKOLA (M.S) INDIA Email: nil.sadanshiv@gmail.com

\begin{abstract}
Summary
A study was carried out to determine the status and distribution of extractable micronutrients zinc $(\mathrm{Zn})$, cupper $(\mathrm{Cu})$, iron $(\mathrm{Fe})$ and manganese $(\mathrm{Mn})$ along a toposequence at Nagpur district, Maharashtra. The twelve profile pits were dug along upper, mid and lower slope positions and soil samples taken from identified horizons were subjected to laboratory analysis. The results show that in toposequence-I, $\mathrm{pH}$ of soils ranged from 6.8 to 8.7 indicating slightly neutral to moderately alkaline soil reaction. The EC of the soils in toposequence-I varied from 0.14 to $0.34 \mathrm{dSm}^{-1}$ and in toposequence-II, it varied from 0.10 to $0.46 \mathrm{dSm}^{-1}$ indicating low soluble salt content. Organic carbon content in toposequence-I ranged from 3.10 to $18.77 \mathrm{~g}$ $\mathrm{kg}^{-1}$ while in toposequence-II, it ranged from 1.55 to $12.77 \mathrm{~g} \mathrm{~kg}^{-1}$ and gradually decreased with depth. Exchangeable cations followed the order: $\mathrm{Ca}^{2+}>\mathrm{Mg}^{2+}>\mathrm{Na}^{+}>\mathrm{K}^{+}$in all the pedons of both the toposequences indicating dominance of calcium bearing minerals in the parent material. Cation exchange capacity in toposequence-I varied from 35.6 to $69.0 \mathrm{cmol}\left(\mathrm{p}^{+}\right) \mathrm{kg}^{-1}$ while in toposequence-II, it varied from 37.8 to $67.2 \mathrm{cmol}\left(\mathrm{p}^{+}\right) \mathrm{kg}^{-1}$. Base saturation of toposequence-I varied from 91 to 127 per cent while in toposequence-II, it varied from 89 to 105 per cent. The DTPA extractable micronutrients followed the order: $\mathrm{Mn}^{2+}>\mathrm{Fe}^{2+}>\mathrm{Cu}^{2+}>\mathrm{Zn}^{2+}$ in toposequence-I and $\mathrm{Fe}^{2+}>\mathrm{Cu}^{2+}>\mathrm{Mn}^{2+}>\mathrm{Zn}^{2+}$ in toposequence-II. Almost all the soils of both the toposequences were deficient in $\mathrm{Zn}^{2+}$, respectively.
\end{abstract}

Key words : Toposequence, Micronutrients, Soil fertility

How to cite this article : Giri, Jaya N., Sadanshiv, Nilima S. and Metkari, Prajakta M.(2017). Status and distribution of available micronutrients along a toposequence at Bazargaon plateau, Maharashtra. Asian J. Soil Sci., 12 (2) : 300-306 : DOI : 10.15740/HAS/AJSS/12.2/300-306. 